\title{
ATTENUATION OF PEAK GROUND ACCELERATIONS IN SOME RECENT NEW ZEALAND EARTHQUAKES
}

\author{
D. J. Dowrick1 and S. Sritharan²
}

\begin{abstract}
SUMMARY
The attenuation of peak ground accelerations was studied for eight New Zealand earthquakes which occurred in the period 1987 to 1991 . These events were of medium size with moment magnitudes in the range $\mathrm{M}_{\mathrm{W}}=$ $5.8-6.7$, with depth to centroids of the fault rupture ranging from 4 to $60 \mathrm{~km}$. Attenuation of peak ground accelerations was examined for each event, based on the slope distance from the rupture surface to each strong motion data site. The mean regression attenuation curve for each event was compared with those derived by others using data sets from other parts of the world, allowance being made for source mechanism and depth. Excepting the 1988 Te Anau event, the other seven New Zealand events as a set closely match a Japanese model, but give significantly stronger accelerations than those predicted by the models from western USA and Europe.
\end{abstract}

\section{INTRODUCTION}

Because of a shortage of suitable local ground motion records, no reliable (statistically robust) model has yet been developed for the attenuation of peak ground acceleration (PGA) in New Zealand. An examination of PGAs was made [1] in 1980, while parallel relationships which have been published are (1) an attenuation model [2] for spectral accelerations developed for loadings code purposes based on a Japanese model, and (2) a recent attempt to do the same from New Zealand data [3]. The Japanese model was adopted because of the geological and tectonic similarities between New Zealand and Japan.

Eight recent New Zealand earthquakes of moderate magnitude in four widely separated parts of the country (Figure 1) yielded sets of strong motion records which give us the opportunity to make a preliminary comparison of attenuation of PGA in New Zealand with the predictions of overseas models, and gain some insights into the true nature of our local attenuation laws. In this interim study the influence of soil condition has not been examined, as a larger data set would be needed to do it justice. This paper is a prelude to a comprehensive study of PGA using all appropriate New Zealand data to be carried out in 1993.

\section{DESCRIPTION OF THE EVENTS}

The source parameters for the earthquakes studied here are summarized in Table 1. Magnitudes are given in terms of $M_{L}$, $\mathrm{M}_{\mathrm{S}}$ and $\mathrm{M}_{\mathrm{W}}$, the latter being derived from the seismic moment $\mathrm{M}_{\mathrm{O}}$ using a relationship which may well be appropriate for New Zealand [4], namely that of Hanks and Kanamori [12]:

$$
M_{W}=\frac{2}{3} \log _{10} M_{O}-6.0
$$

1,2 DSIR Physical Sciences, now of the Institute of Geological \& Nuclear Sciences, Lower Hutt, New Zealand. ${ }^{1}$ Fellow

${ }^{2}$ Member where $\mathrm{M}_{\mathrm{O}}$ is in $\mathrm{Nm}$.

The $M_{S}, M_{W}$ data from these events conform well to the model suggested by earlier events [4], which showed that for shallow events $M_{S}$ equates to $M_{W}$ for $M \geq 6$.

In Table 1 , two depths are given, namely the focal depth, $h$, and the depth to the centroid of the rupture surface, $h_{e}$. The latter approximates to the centre of energy release, and has been termed effective depth in two recent studies, one of magnitudes [4] and the other of attenuation of intensity [13,14]. For six of the earthquakes in Table $1, h_{e}$ was determined in evaluations of seismic moments $[7,8]$.

\section{GROUND MOTION DATA}

In the eight events a total of 92 strong motion records were obtained, at horizontal distances from the source ranging from $8 \mathrm{~km}$ to $280 \mathrm{~km}$. Peak ground accelerations were obtained from digital, mechanical-optical (MO1, MO2 and MO2A) and scratch plate (SP) instruments. Detailed digital descriptions of strong motion data from the Edgecumbe, Weber and Hawks Crag earthquakes have previously been published in DSIR reports $[15,16,17]$. Note that in the latter volume the Hawks Crag events are sometimes referred to under their initial provisional name, i.e. the Paparoa earthquakes. Source parameter data given in Table 1 is to be preferred to any conflicting data in Refs $15-17$, as Table 1 is based on the latest analyses in some cases carried out since the completion of those reports.

The PGA data used in this study are given in Table 2, with PGAs of some events plotted in Figures 2-6. The data comprises PGAs in two horizontal directions for each record, namely instrument axes for time based accelerographs, and NS and EW for SP instruments. The largest acceleration of our data set is $0.376 \mathrm{~g}$ which was recorded in Dannevirke in the second Weber event at a distance of $21 \mathrm{~km}$ from the rupture surface . 


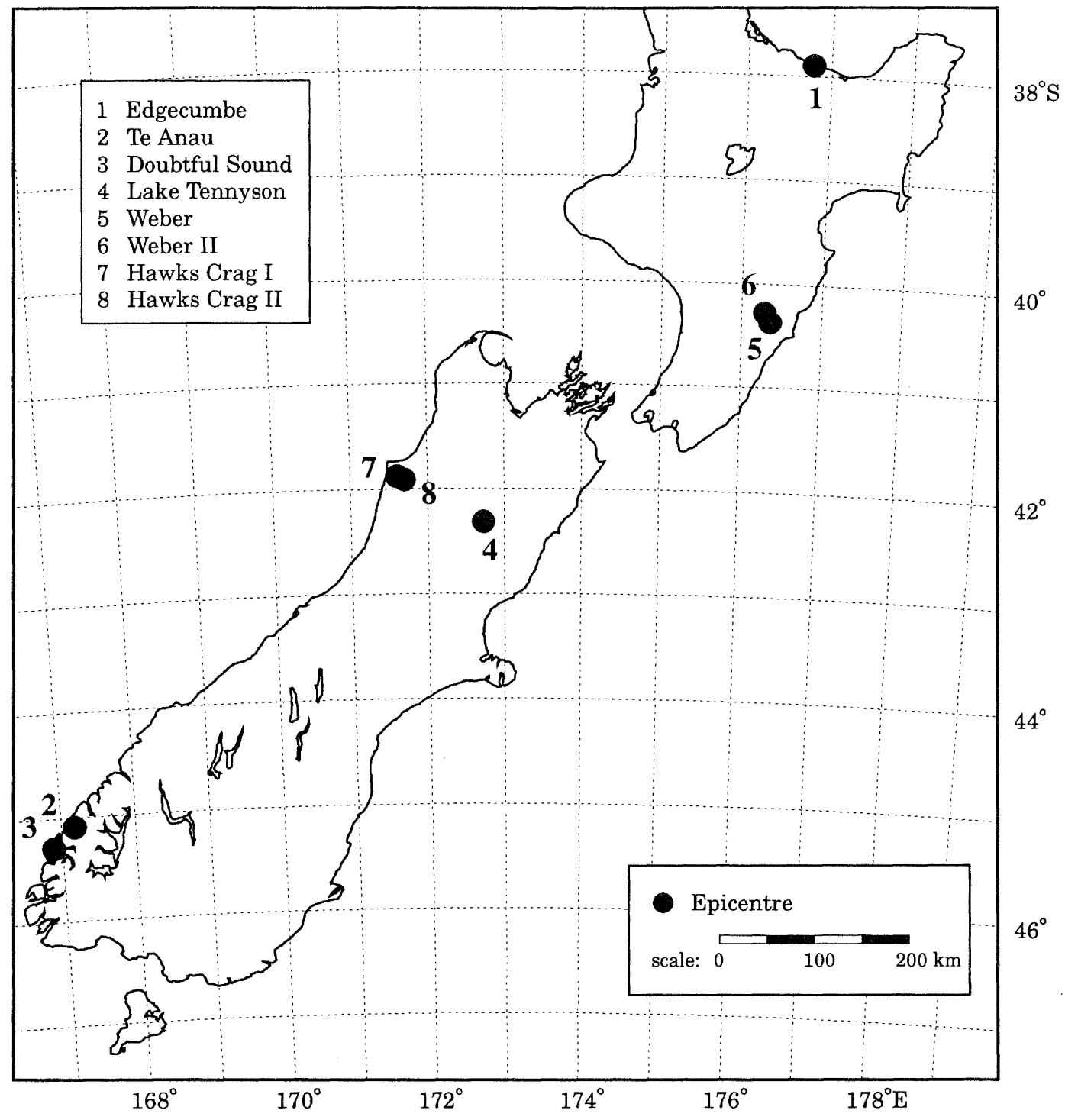

Fig. 1 Map of New Zealand showing epicentral locations of the eight earthquakes involved in this study. The event numbers correspond to those given in Tables $1-3$.

\section{REGRESSION ANALYSES}

For the purposes of this study we adopted an attenuation expression of the form

$$
\log _{10} P G A=a+b M+c r+d \log _{10} r
$$

where

a, b, c, d are empirical regression coefficients, $M$ is magnitude

$r$ is slope distance from the source, such that

$$
r=\left(r_{h}^{2}+h_{s}^{2}\right)^{1 / 2}
$$

where $r_{h}$ is the horizontal distance from the vertical projection of the source, and $h_{s}$ is the depth of the source. Alternative detailed definitions of $r_{h}$ and $h_{s}$ were used as discussed later.
Equation (2) is the same form as that used for attenuation models by various workers, e.g. for PGA by Joyner and Boore [18] and Ambraseys and Bommer [19], and for intensity for New Zealand earthquakes by Dowrick $[13,14]$.

The terms $r$ and $\log r$ in the equation (2) relate respectively to anelastic attenuation and geometrical spreading of the seismic waves.

Some other researchers, e.g. Campbell [20] and Fukushima and Tanaka [21], included an additional magnitude dependent term in their attenuation expressions in order to constrain the amplitude and attenuation of the ground acceleration near the fault rupture. With this additional term, the attenuation expression takes the following form

$$
\log P G A=a+b M+c r+d \log (r+f(M))
$$

where $\mathrm{f}(\mathrm{M})$ is a function of magnitude and the other parameters are as defined above. 
Table 1: Source parameters of eight recent New Zealand earthquakes

\begin{tabular}{|c|c|c|c|c|c|c|c|c|c|c|c|c|c|}
\hline & \multirow[t]{2}{*}{ Event } & \multirow[t]{2}{*}{$\mathbf{M}_{\mathbf{L}}$} & \multirow[t]{2}{*}{$\mathbf{M}_{\mathbf{S}}$} & \multirow[t]{2}{*}{$\mathbf{M}_{\mathrm{w}}$} & \multirow{2}{*}{$\begin{array}{c}\mathrm{M}_{0} \\
\left(10^{17} \mathrm{Nm}\right)\end{array}$} & \multicolumn{2}{|c|}{ Epicentre } & \multicolumn{2}{|c|}{$\begin{array}{l}\text { Centroid* of } \\
\text { rupture surface }\end{array}$} & \multicolumn{2}{|c|}{ Depth (kma) } & \multirow{2}{*}{$\begin{array}{l}\text { Fault } \\
\text { Rupture } \\
\text { Length } \\
\text { (km) }\end{array}$} & \multirow{2}{*}{$\begin{array}{c}\text { Predominant } \\
\text { Source } \\
\text { Mechanism }\end{array}$} \\
\hline & & & & & & ${ }^{\circ} \mathrm{S}$ & ${ }^{\circ} \mathrm{E}$ & ${ }^{\circ} \mathrm{S}$ & ${ }^{\circ} \mathrm{E}$ & $\mathbf{h}$ & $\mathbf{h}_{e}$ & & \\
\hline 1 & $\begin{array}{l}1987 \text { Mar } 02 \\
\text { Edgecumbe }\end{array}$ & 6.1 & $6.6[4]$ & $\begin{array}{l}6.5 \\
6.4 \\
\end{array}$ & $\begin{array}{ll}64 & {[6]} \\
43 & {[5]} \\
\end{array}$ & 37.89 & 176.80 & 37.96 & 176.81 & 8 & 4 & $13[11]$ & Normal \\
\hline 2 & $\begin{array}{l}1988 \text { Jun } 03 \\
\text { Te Anau }\end{array}$ & 6.1 & $6.7[4]$ & $\begin{array}{l}6.7 \\
6.7\end{array}$ & $\begin{array}{ll}120 & {[6]} \\
119 & {[7]}\end{array}$ & 45.10 & 167.17 & 45.05 & 167.1 & 57 & 60 & $20 *$ & Reverse \\
\hline 3 & $\begin{array}{c}1989 \text { May } 31 \\
\text { Doubtful Sound }\end{array}$ & 6.0 & $6.2[9]$ & $\begin{array}{l}6.4 \\
6.4 \\
\end{array}$ & $\begin{array}{ll}53 & {[6]} \\
34.5 & {[7]} \\
\end{array}$ & 45.27 & 166.88 & $\begin{array}{l}\text { Not a) } \\
\text { Epicen }\end{array}$ & $\begin{array}{l}\text { ilable, } \\
\text { re used }\end{array}$ & 23 & 24 & $\nabla$ & Strike-slip \\
\hline 4 & $\begin{array}{l}1990 \text { Feb } 10 \\
\text { Lake Tennyson }\end{array}$ & 5.8 & $5.9[9]$ & $\begin{array}{l}6.0 \\
6.0\end{array}$ & $\begin{array}{ll}11.0 & {[6]} \\
8.7 & {[7]}\end{array}$ & 42.32 & 172.74 & 42.26 & 172.72 & 12 & 8 & $21 *$ & Strike-slip \\
\hline 5 & $\begin{array}{c}1990 \text { Feb } 19 \\
\text { Weber I }\end{array}$ & 5.9 & $6.3[9]$ & 6.3 & $27.0 \quad[6]$ & 40.36 & 176.36 & 40.34 & 176.35 & 24 & $28^{*}$ & $13^{*}$ & Normal \\
\hline 6 & $\begin{array}{l}1990 \text { May } 13 \\
\text { Weber II }\end{array}$ & 6.2 & 6.2 [9] & $\begin{array}{l}6.4 \\
6.4\end{array}$ & $\begin{array}{ll}46.0 & {[6]} \\
52.6 & {[8]}\end{array}$ & 40.28 & 176.30 & 40.31 & 176.32 & 12 & 13 & $18 *$ & Reverse \\
\hline 7 & $\begin{array}{l}1991 \text { Jan } 28 \\
\text { Hawks Crag I }\end{array}$ & $\begin{array}{l}5.9 \\
(\mathrm{P}) \\
\end{array}$ & $5.3[10]$ & $\begin{array}{l}5.8 \\
5.8 \\
\end{array}$ & $\begin{array}{ll}4.4 & {[6]} \\
5.3 & {[7]} \\
\end{array}$ & 41.89 & 171.58 & $\begin{array}{l}\text { Not ar } \\
\text { Epicen }\end{array}$ & $\begin{array}{l}\text { ilable, } \\
\text { re used }\end{array}$ & 8 & 10 & $\nabla$ & Reverse \\
\hline 8 & $\begin{array}{c}1991 \text { Jan } 28 \\
\text { Hawks Crag II }\end{array}$ & $\begin{array}{l}6.0 \\
(\mathrm{P})\end{array}$ & $5.6[10]$ & $\begin{array}{l}5.9 \\
6.0\end{array}$ & $\begin{array}{ll}7.0 & {[6]} \\
8.7 & {[7]}\end{array}$ & 41.90 & 171.67 & $\begin{array}{l}\text { Not a } \\
\text { Epicen }\end{array}$ & $\begin{array}{l}\text { ilable, } \\
\text { e used }\end{array}$ & 13 & 12 & $\nabla$ & Reverse \\
\hline
\end{tabular}

Notes: $\quad *=$ Estimated by the authors from aftershocks plotted by NZ Seismological Observatory.

$\nabla=$ Aftershock plots not available

$\mathrm{P}=$ Preliminary estimate

Table 2: $\quad$ Strong-motion data used in this study

\begin{tabular}{|c|c|c|c|}
\hline Site Location & $\begin{array}{l}\text { Horizontal Distance } \\
\text { to the Source }(\mathrm{km})\end{array}$ & \multicolumn{2}{|c|}{$\begin{array}{l}\text { Peak Ground Acceleration } \\
(\mathrm{g})\end{array}$} \\
\hline \multicolumn{4}{|l|}{$1 \%$ Edgecumbe } \\
\hline $\begin{array}{l}\text { Matahina } \\
\text { Opotoki } \\
\text { Maraenui } \\
\text { Wairoa }\end{array}$ & $\begin{array}{r}14.5^{*} \\
37.3^{*} \\
62.9^{*} \\
129.8^{*} \\
\end{array}$ & $\begin{array}{l}0.283 \\
0.098 \\
0.034 \\
0.021\end{array}$ & $\begin{array}{l}0.241 \\
0.068 \\
0.037 \\
0.014\end{array}$ \\
\hline \multicolumn{4}{|l|}{$2 \quad \mathrm{Te}$ Anau } \\
\hline $\begin{array}{l}\text { Te Anau } \\
\text { Mossburn } \\
\text { Queenstown } \\
\text { Wanaka National Park } \\
\text { Cromwell Bridge (rock) } \\
\text { Invercargill } \\
\text { Roxburgh } \\
\text { Gore } \\
\text { Haast } \\
\text { Lauder } \\
\text { Omarama } \\
\text { Dunedin P O } \\
\end{array}$ & $\begin{array}{l}63.4 \ddagger \\
112.9 \ddagger \\
122.8 \ddagger \\
165.7 \ddagger \\
167.0 \ddagger \\
179.9 \ddagger \\
181.8 \ddagger \\
185.1 \ddagger \\
201.0 \ddagger \\
202.0 \ddagger \\
235.0 \ddagger \\
280.8 \ddagger \\
\end{array}$ & $\begin{array}{l}0.105 \\
0.038 \\
0.135 \\
0.033 \\
0.061 \\
0.015 \\
0.031 \\
0.032 \\
0.068 \\
0.030 \\
0.022 \\
0.022 \\
\end{array}$ & $\begin{array}{l}0.095 \\
0.044 \\
0.144 \\
0.040 \\
0.045 \\
0.013 \\
0.026 \\
0.041 \\
0.059 \\
0.025 \\
0.018 \\
0.020 \\
\end{array}$ \\
\hline \multicolumn{4}{|l|}{$3 \quad$ Doubtful Sound } \\
\hline $\begin{array}{l}\text { Manapouri } \\
\text { Te Anau } \\
\text { Queenstown } \\
\text { Gore }\end{array}$ & $\begin{array}{r}43.8 \nabla \\
67.6 \nabla \\
142.2 \nabla \\
184.9 \nabla \\
\end{array}$ & $\begin{array}{l}0.140 \\
0.096 \\
0.023 \\
0.028 \\
\end{array}$ & $\begin{array}{l}0.066 \\
0.063 \\
0.035 \\
0.030 \\
\end{array}$ \\
\hline \multicolumn{4}{|l|}{$4 \quad$ Lake Tennyson } \\
\hline $\begin{array}{l}\text { Hanmer Springs } \\
\text { Springs Junction } \\
\text { Murchison } \\
\text { Reefton } \\
\text { Harewood } \\
\text { Picton } \\
\text { MONZ } \\
\end{array}$ & $\begin{array}{r}29.1^{*} \\
38.6^{*} \\
61.0^{*} \\
68.0^{*} \\
131.8^{*} \\
138.0^{*} \\
187.5^{*} \\
\end{array}$ & $\begin{array}{l}0.098 \\
0.036 \\
0.023 \\
0.015 \\
0.025 \\
0.009 \\
0.004\end{array}$ & $\begin{array}{l}0.130 \\
0.049 \\
0.027 \\
0.014 \\
0.029 \\
0.009 \\
0.004\end{array}$ \\
\hline
\end{tabular}




\begin{tabular}{||l|c|c|c||}
\hline \multicolumn{1}{|c|}{ Site Location } & $\begin{array}{c}\text { Horizontal Distance } \\
\text { to the Source } \mathbf{( k m )}\end{array}$ & \multicolumn{2}{|c|}{$\begin{array}{c}\text { Peak Ground Acceleration } \\
\mathbf{( g )}\end{array}$} \\
\hline W Weber I & \multicolumn{3}{|c||}{} \\
\hline Dannevirke Telecom & $25.6^{*}$ & 0.300 & 0.151 \\
Woodville P O & $37.9^{*}$ & 0.147 & 0.219 \\
Pahiatua & $40.3^{*}$ & 0.087 & 0.125 \\
Waipawa P O & $44.7^{*}$ & 0.151 & 0.203 \\
Castlepoint & $58.3^{*}$ & 0.075 & 0.090 \\
Massey University Tunnel & $58.8^{*}$ & 0.048 & 0.054 \\
Palmerston North & $59.0^{*}$ & 0.045 & 0.042 \\
South Rangitikei & $75.9^{*}$ & 0.027 & 0.024 \\
Hastings & $82.9^{*}$ & 0.044 & 0.037 \\
Masterton & $83.8^{*}$ & 0.014 & 0.018 \\
Ohakea & $84.1^{*}$ & 0.036 & 0.031 \\
Napier Museum & $101.4^{*}$ & 0.026 & 0.026 \\
Martinborough & $117.1^{*}$ & 0.020 & 0.027 \\
Karioi Pulp Mill & $117.3^{*}$ & 0.038 & 0.034 \\
Wanganui P O & $117.6^{*}$ & 0.019 & 0.025 \\
Atene (Puketapu) & $123.5^{*}$ & 0.039 & 0.063 \\
NZGS & $150.3^{*}$ & 0.009 & 0.012 \\
INS & $150.7^{*}$ & 0.004 & 0.005 \\
PEL & $151.0^{*}$ & 0.011 & 0.011 \\
Reserve Bank & $163.5^{*}$ & 0.005 & 0.008 \\
MONZ & $163.8^{*}$ & 0.007 & 0.006 \\
Seismological Observatory & $164.2^{*}$ & 0.006 & 0.007 \\
Wellington Airport & $164.5^{*}$ & 0.012 & 0.005 \\
\hline
\end{tabular}

\begin{tabular}{|c|c|c|c|}
\hline Site Location & $\begin{array}{l}\text { Horizontal Distance } \\
\text { to the Source }(\mathbf{k m})\end{array}$ & \multicolumn{2}{|c|}{$\begin{array}{c}\text { Peak Ground Acceleration } \\
(\mathrm{g})\end{array}$} \\
\hline \multicolumn{4}{|l|}{ Weber II } \\
\hline Dannevirke P O & $21.3^{*}$ & 0.255 & 0.376 \\
\hline Woodville P O & $32.7^{*}$ & 0.168 & 0.153 \\
\hline Pahiatua & $35.6^{*}$ & 0.145 & 0.154 \\
\hline Waipawa P O & $38.9 *$ & 0.192 & 0.248 \\
\hline Massey University Tunnel & $53.7^{*}$ & 0.043 & 0.046 \\
\hline Palmerston North & $53.9 *$ & 0.036 & 0.031 \\
\hline Castlepoint & $59.0 *$ & 0.065 & 0.054 \\
\hline Hastings & $77.4^{*}$ & 0.059 & 0.049 \\
\hline Ohakea & $78.9^{*}$ & 0.034 & 0.033 \\
\hline Taihape & $81.3^{*}$ & 0.058 & 0.076 \\
\hline Masterton & $81.5^{*}$ & 0.031 & 0.022 \\
\hline Levin & $85.8^{*}$ & 0.041 & 0.053 \\
\hline Otaki & $102.7^{*}$ & 0.053 & 0.031 \\
\hline Karioi Pulp Mill & $111.5^{*}$ & 0.049 & 0.031 \\
\hline Wanganui P O & $112.5^{*}$ & 0.065 & 0.034 \\
\hline Martinborough & $115.0^{*}$ & 0.014 & 0.016 \\
\hline Atene (Puketapu) & $118.7^{*}$ & 0.073 & 0.080 \\
\hline Paraparaumu & $121.4^{*}$ & 0.041 & 0.041 \\
\hline Te Marua & $123.5^{*}$ & 0.016 & 0.013 \\
\hline Ohakune & $125.2^{*}$ & 0.039 & 0.038 \\
\hline INS & $147.6^{*}$ & 0.005 & 0.007 \\
\hline PEL & $147.9^{*}$ & 0.024 & 0.019 \\
\hline Reserve Bank & $160.2^{*}$ & 0.011 & 0.011 \\
\hline Taranaki Street & $160.8^{*}$ & 0.012 & 0.012 \\
\hline Seismological Observatory & $161.0^{*}$ & 0.009 & 0.011 \\
\hline Wellington Airport & $161.4^{*}$ & 0.002 & 0.005 \\
\hline \multicolumn{4}{|l|}{$7 \quad$ Hawks Crag I } \\
\hline Te Kuha & $9.2 \nabla$ & 0.207 & 0.120 \\
\hline Westport & $14.8 \nabla$ & 0.139 & 0.140 \\
\hline Inangahua & $31.4 \nabla$ & 0.110 & 0.051 \\
\hline Reefton & $34.4 \nabla$ & 0.059 & 0.065 \\
\hline Murchison & $61.1 \nabla$ & 0.103 & 0.124 \\
\hline Hanmer Springs & $125.0 \nabla$ & 0.027 & 0.019 \\
\hline Seismological Observatory & $273.5 \nabla$ & 0.002 & 0.002 \\
\hline MONZ & $274.4 \nabla$ & 0.003 & 0.005 \\
\hline
\end{tabular}




\begin{tabular}{||l|c|c|c|}
\hline \multicolumn{1}{|c|}{ Site Location } & \multicolumn{2}{c|}{$\begin{array}{c}\text { Horizontal Distance } \\
\text { to the Source } \mathbf{( k m )}\end{array}$} & $\begin{array}{c}\text { Peak Ground Acceleration } \\
\mathbf{( g )}\end{array}$ \\
\hline 8 Hawks Crag II & \multicolumn{3}{|c|}{} \\
\hline Te Kuha & $7.5 \nabla$ & 0.125 & 0.112 \\
Westport & $16.9 \nabla$ & 0.141 & 0.158 \\
Inangahua & $24.2 \nabla$ & 0.185 & 0.168 \\
Reefton & $29.0 \nabla$ & 0.177 & 0.133 \\
Murchison & $53.9 \nabla$ & 0.223 & 0.225 \\
Hanmer Springs & $118.3 \nabla$ & 0.031 & 0.018 \\
MONZ & $267.4 \nabla$ & 0.007 & 0.006 \\
PEL & $280.0 \nabla$ & 0.005 & 0.002 \\
\hline
\end{tabular}

Notes: $\quad *=$ nearest horizontal distance to the surface projection of the fault at centroid depth.

$\ddagger=$ horizontal distance to the centroid.

$\nabla=$ horizontal distance to the epicentre.

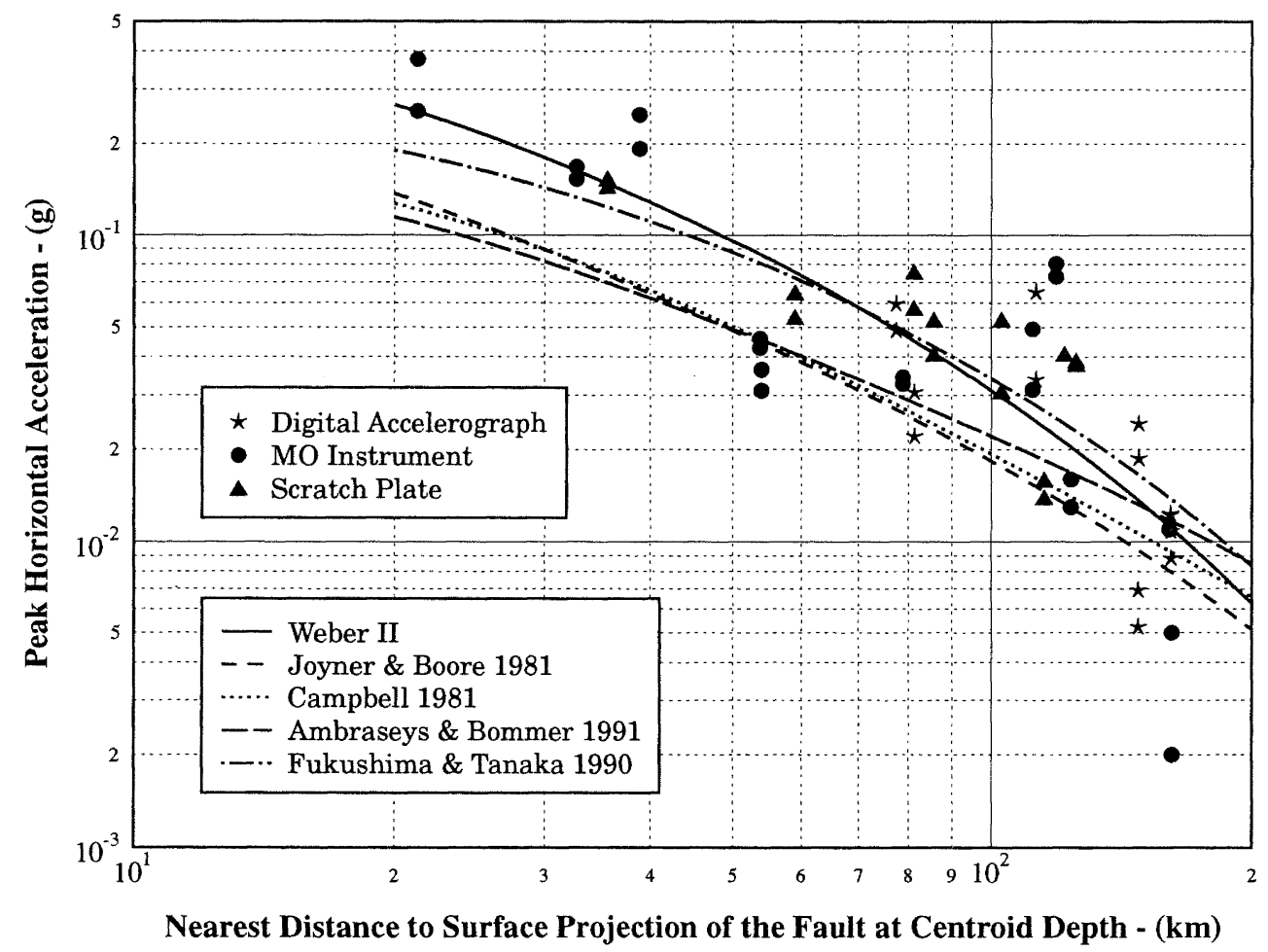

Fig. 2 PGA data and regression curve for the $\mathrm{M}_{\mathrm{w}}=6.4$ Weber II earthquake of May 1990 , compared with attenuation models from other regions. 


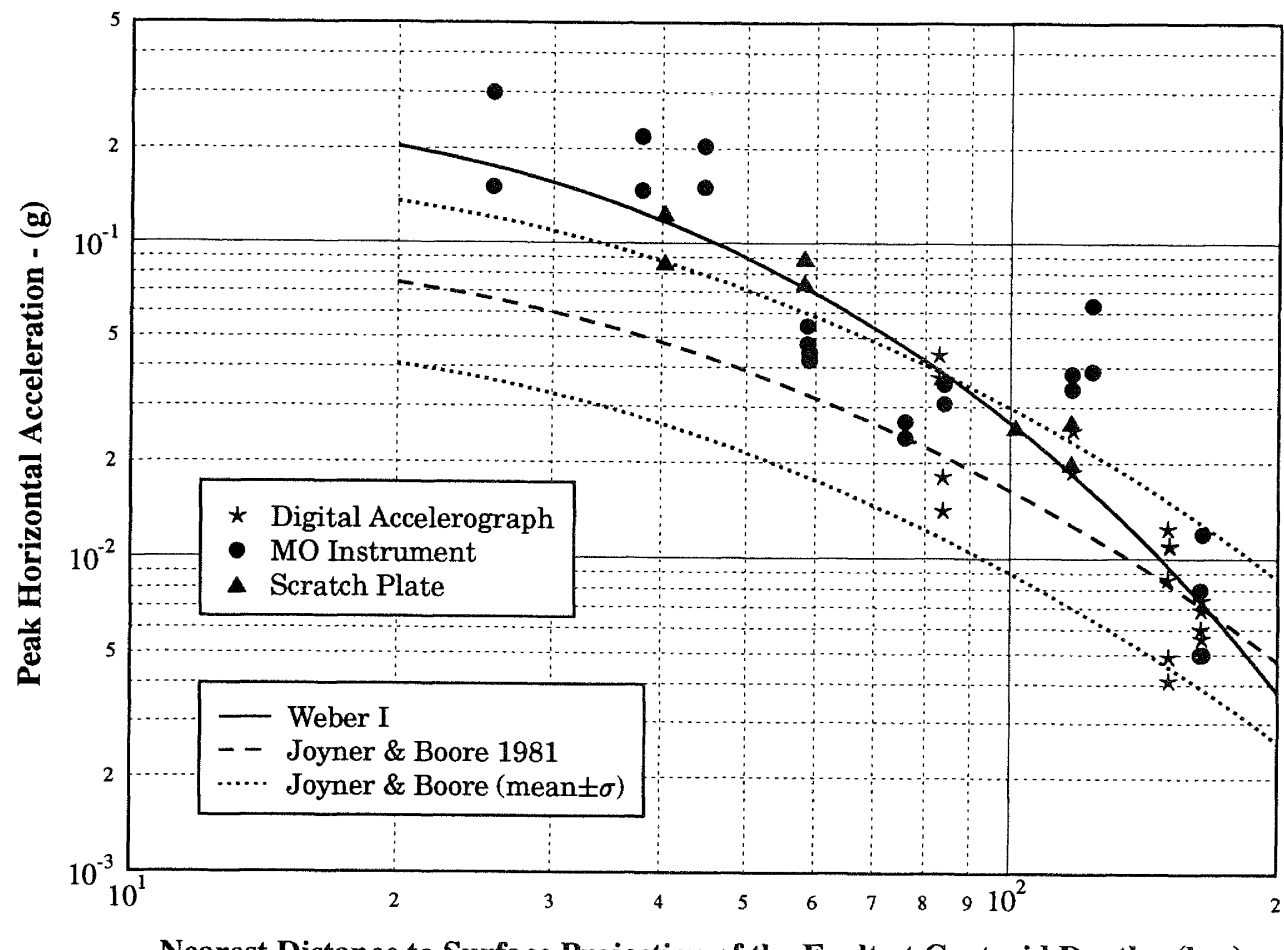

Nearest Distance to Surface Projection of the Fault at Centroid Depth - (km)

Fig. 3 PGA data and regression curve for the $M_{w}=6.3$ Weber I earthquake of February 1990, compared with the attenuation model of Joyner and Boore (depth adjusted).

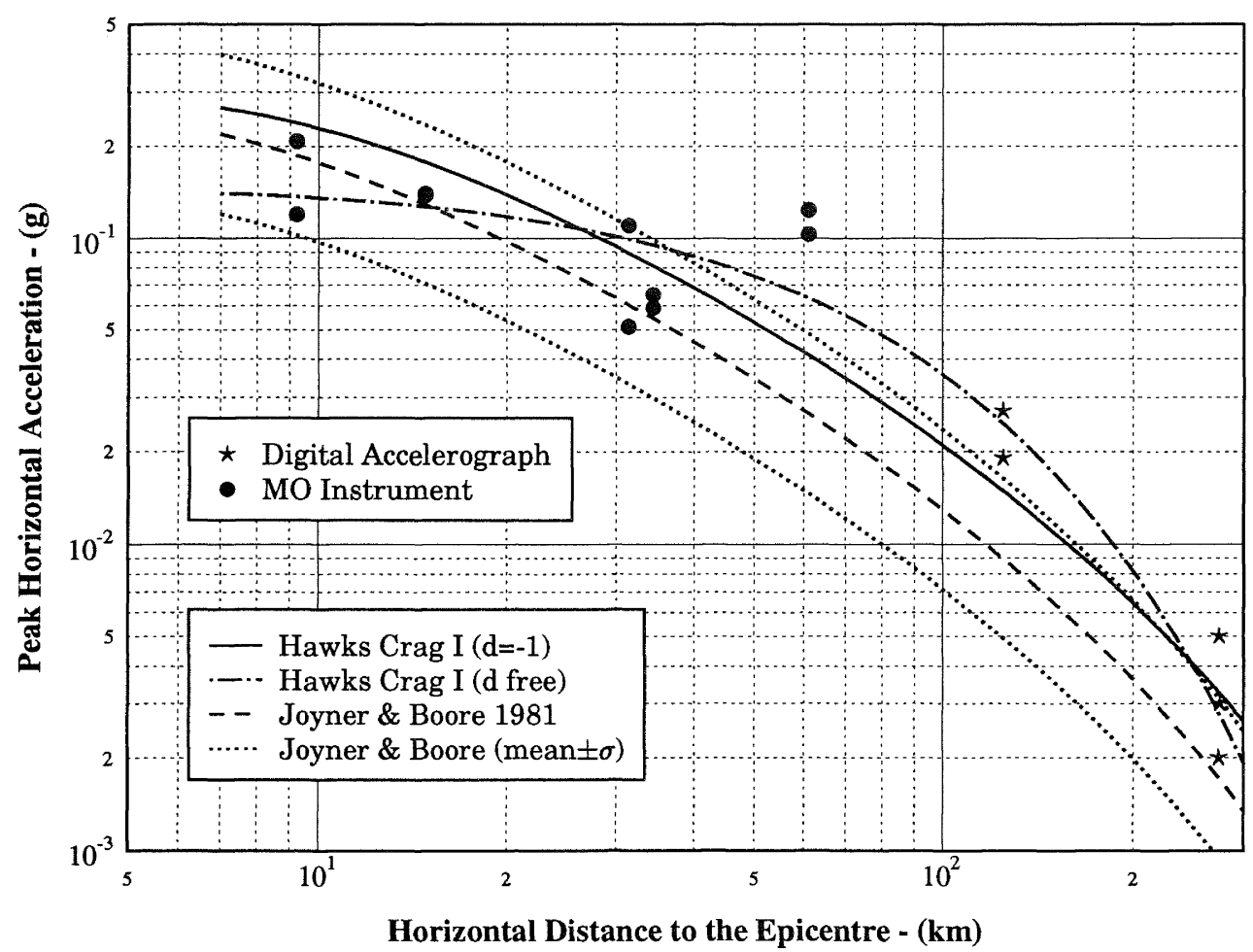

Fig. 4 PGA data and regression curve for the $M_{w}=5.8$ Hawks Crag I earthquake of January 1991, compared with the attenuation model of Joyner and Boore (depth adjusted). 


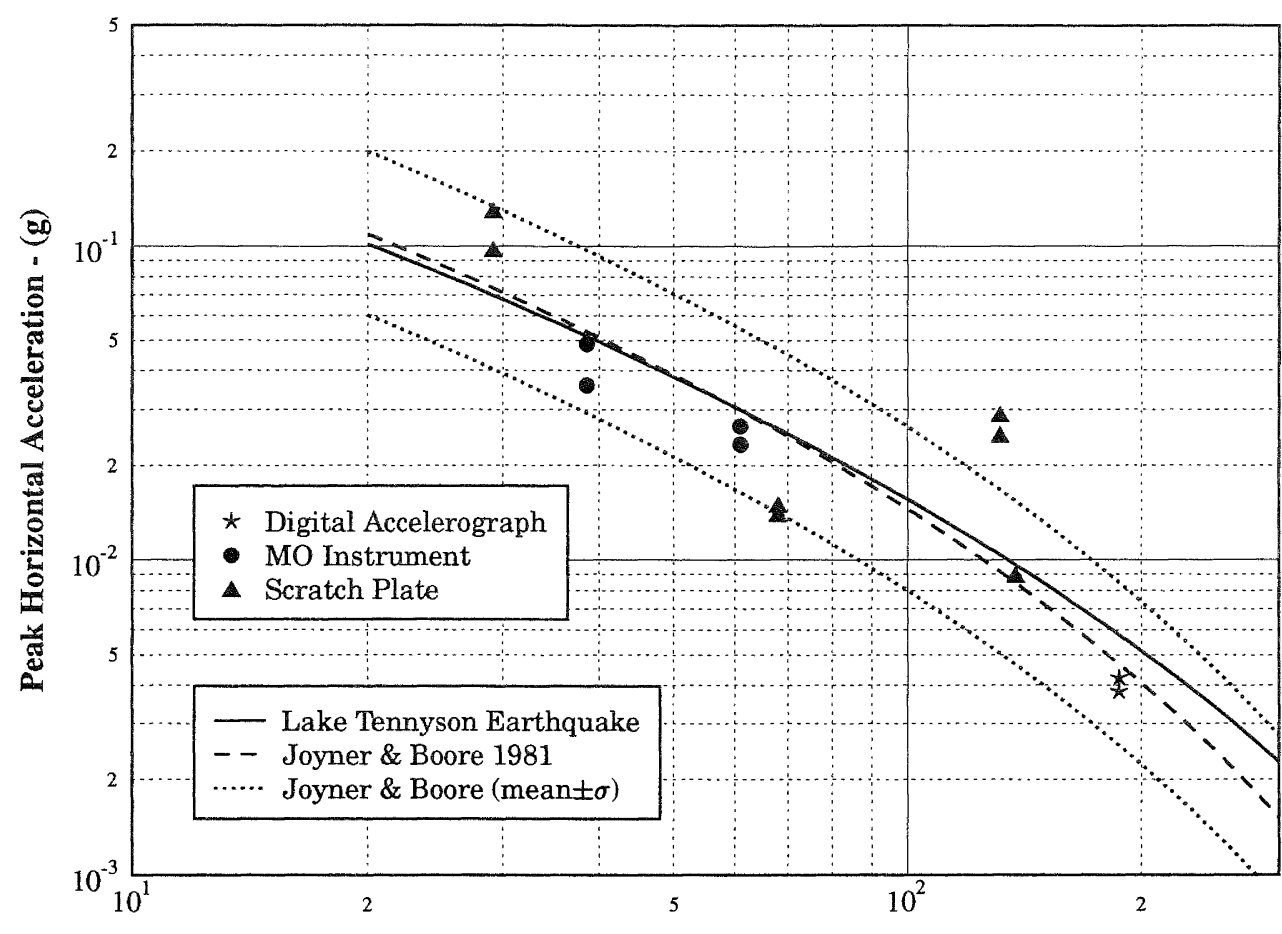

Nearest Distance to Surface Projection of the Fault at Centroid Depth - (km)

Fig. 5 PGA data and regression curve for the $\mathrm{M}_{\mathrm{w}}=6.0$ Lake Tennyson earthquake of February 1990, compared with the attenuation model of Joyner and Boore (depth adjusted).

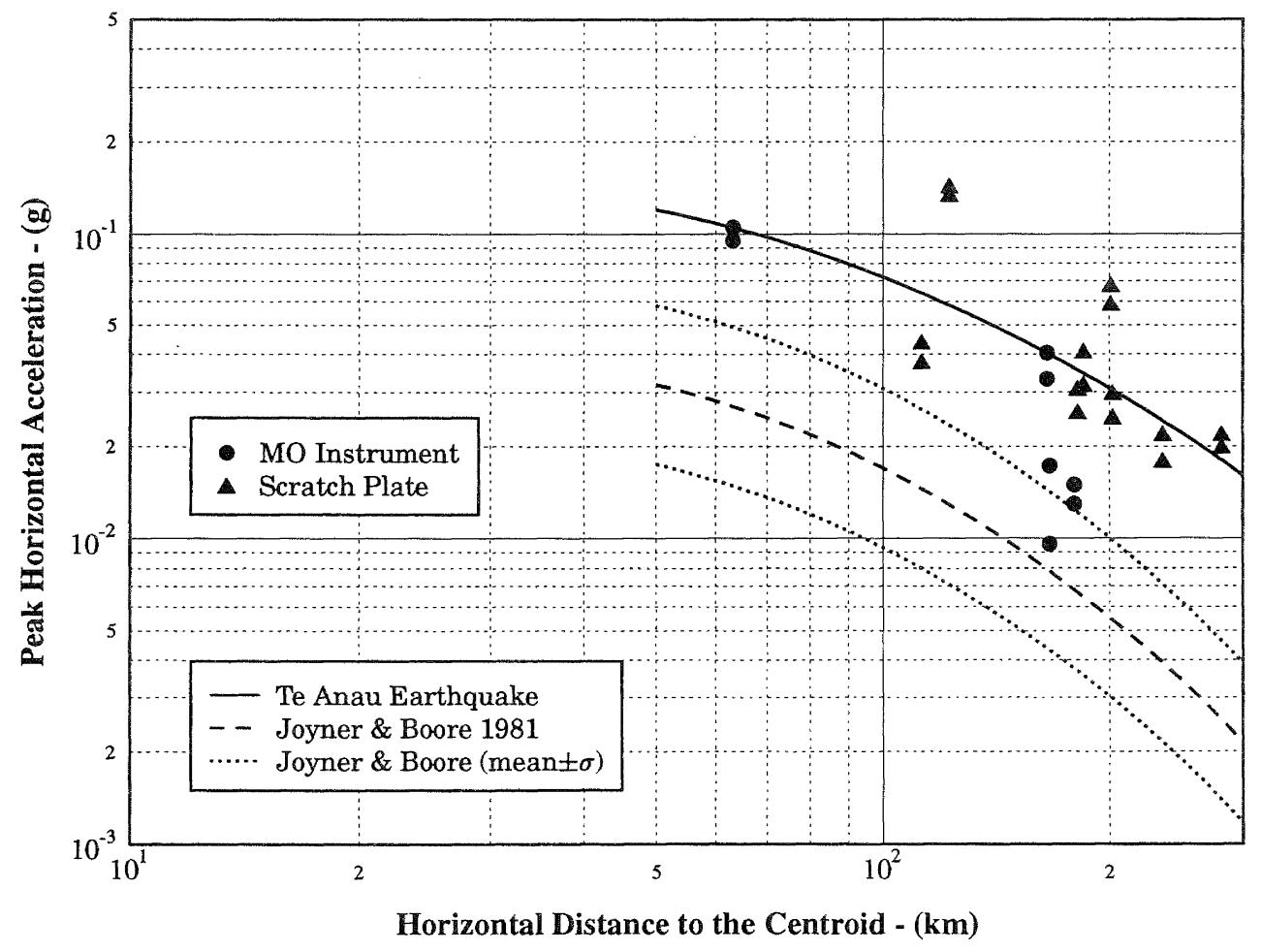

Fig. 6 PGA data and regression curve for the $M_{w}=6.7 \mathrm{Te}$ Anau earthquake of February 1988, compared with the attenuation model of Joyner and Boore (depth adjusted). 
For large values of $r$, the term $\log (r+f(M))$ in equation (4) becomes nearly equal to $\log (r)$, so that equation (4) in effect reduces to equation (2).

The fact that we have ignored this additional term constraining near source accelerations is not philosophically significant, since at this stage we are not seeking to establish a model of the near source region. In any case in the medium magnitude range of the events under consideration, the effect of such a constraint is small.

For calculating regression coefficients for a set of data obtained from a single event, the expression given in equation (2) can be reduced to

$$
\log P G A=a^{\prime}+c r+d \log r
$$

where $\mathrm{a}^{\prime}, \mathrm{c}$ and $\mathrm{d}$ are empirical regression coefficients.

The coefficient $d$ associated with the geometrical spreading function $\log r$ is assigned a value of $d=-1$ in some attenuation models $[18,19,21]$. This corresponds to body wave attenuation from a point source in a homogeneous medium. Joyner and Boore [22] and Ambraseys and Bommer [19] also suggested that the distribution of their data does not allow for meaningful simultaneous determination of coefficients for geometrical spreading and anelastic attenuation, so that adopting $\mathrm{d}=-1$ allows $\mathrm{c}$ to be "properly" determined.

However the restriction of $d$ to unity is not demanded physically $[19,22,23]$, as different seismic waves have different geometrical spreading dependence. Considering their European data set, Ambraseys and Bommer [19] compared the use of $\mathrm{d}=-1$ with that appropriate if considering only the Airy phase when $d=-0.83$. They considered that their value of $c$ was much more realistic in the latter case. We estimated coefficients $\mathrm{a}^{\prime}$ and $\mathrm{c}$ of equation (5), from regression analysis assuming $\mathrm{d}=-1$. Sensitivity of restraining the $\mathrm{d}$ value was also investigated for some of the earthquakes in this study by calculating all three coefficients, $a^{\prime}, c$ and $d$, from regression analysis. One of the events which was affected most is discussed later.

For each earthquake data set linear regression analyses were carried out using both horizontal components to find the best fit attenuation curve. In this study no attempt has been made to differentiate between records obtained at sites with different ground conditions, and all data were included. The attenuation curves for the New Zealand earthquakes were compared with the mean regression curves obtained using four overseas models, namely those of the western USA [18,20], Japan [21] and Europe [19]. Joyner and Boore's [18] expression is

$$
\begin{array}{r}
\log _{10}(P G A)_{s}=-1.02+0.249 M_{W} \\
-0.00255 r_{j}-\log _{10} r_{j} \\
r_{j}=\left(r_{f h}^{2}+7.3^{2}\right)^{1 / 2}
\end{array}
$$

where $r_{\mathrm{fh}}$ is the shortest horizontal distance to the surface projection of the fault rupture in $\mathrm{km}$, and $(\mathrm{PGA})_{\mathrm{s}}$ is the stronger of the two horizontal components in $\mathrm{g}$.
Campbell's [20] expression (constrained model) is

$$
\begin{aligned}
(P G A)_{m} & =0.0185 \exp (1.28 M)\left[r_{f}\right. \\
& +0.147 \exp (0.732 M)]^{-1.75}
\end{aligned}
$$

where $(\mathrm{PGA})_{\mathrm{m}}$ is the mean of the two horizontal components of PGA in $g$; $M$ is $M_{S}$ or $M_{L}$ depending on size [20], $r_{f}$ is the shortest distance to the fault rupture (slope distance) in $\mathrm{km}$. Campbell found that the stronger of the two horizontal components was 13 percent larger than $(\mathrm{PGA})_{\mathrm{m}}$ on average. $(\mathrm{PGA})_{\mathrm{s}}$ values predicted by two of the empirical models (equations (6) and (10)) were therefore reduced by 13 percent for comparison purposes.

Fukushima and Tanaka's [21] expression is

$$
\begin{aligned}
\log _{10}(P G A)_{m} & =1.30+0.41 M_{s}-0.0034 r_{f} \\
& -\log _{10}\left[r_{f}+0.032\left(10^{0.41 M_{s}}\right)\right]
\end{aligned}
$$

where $(P G A)_{m}$ is in $\mathrm{cm} / \mathrm{s}^{2}$ and $r_{\mathrm{f}}$ is in $\mathrm{km}$.

Because of paucity of the near-field data from earthquakes in Japan, Fukushima and Tanaka used near-field data obtained in the USA and other countries. Accelerations of these overseas data points were increased by 46 percent to compensate for the difference seen between Japanese and non-Japanese data. However we have some concerns that their data is not homogeneous and this model should be treated with caution.

Ambraseys and Bommer's [19] expression when allowing for the effect of focal depth $h$ is

$$
\begin{aligned}
\log _{10}(P G A)_{s}= & -0.87+0.217 M_{s} \\
& -0.00117 r_{a}-\log _{10} r_{a} \\
r_{a}= & \left(r_{f h}^{2}=h^{2}\right)^{1 / 2}
\end{aligned}
$$

where $(P G A)_{s}$ is in $\mathrm{g}$ and $r_{a}$ is in $\mathrm{km}$.

It is seen that $M_{W}$ is used in equation (6), $M_{s}$ or $M_{L}$ is used in equation (8) and $M_{S}$ is used in equations (9) and (10). For the purposes of the comparisons made in this study we have used $M_{W}$ in all cases (the larger of the two values given for each event in Table 1). For events 1-6 (Table 1) $M_{s} \approx M_{w}$. In the case of events 7 and $8 M_{S}$ is oddly low and $M_{W}$ is considered to be more reliable.

In Figure 2 are plotted the PGA data for the $\mathrm{M}_{\mathrm{W}}=6.4$ Weber earthquake of 13 May 1990, together with the mean regression curve obtained using the depth $h_{e}=13 \mathrm{~km}$. Horizontal distances were measured from each instrument to the nearest point on the surface projection of the fault rupture at depth $h_{e}$ as determined from the aftershock pattern of Robinson [24]. While two of the models measure horizontal distances from the surface projection of the fault rupture, we have used $h_{e}$ almost throughout (except where noted) for consistency in the comparisons. The difference in the horizontal distance that results from the choice of surface projection of the fault rupture and surface projection of the rupture at depth $h_{e}$ is small in all our cases. In the regression expression, equation (5), it was 
assumed that $d=-1$ and standard error, $\sigma$, of 0.26 was obtained for $\log (\mathrm{PGA})$.

Also plotted on Figure 2 are the curves predicted for an event of this magnitude by the four models from other regions as indicated. As the event is quite shallow Joyner and Boore's model has been applied without depth adjustment (i.e. using their $\mathrm{h}=7.3 \mathrm{~km}$ ) while for the other models the depth $h_{e}=13 \mathrm{~km}$ was used. As this event is a reverse fault mechanism, the values obtained from Campbell's model have been multiplied by 1.2 to allow for the 1.28 difference between reverse and non-reverse fault events reported by him in 1981 [20]. Campbell has since developed another model for reverse faults, but it has only been published second hand by others (in Ref. 22). For the present purposes we deemed that his 1981 model sufficed.

Comparing the regression line with the other models it is evident that European and USA models substantially underestimate the accelerations recorded in this event, while the Japanese model matches the regression line much better.

In Figure 3 are plotted the PGA data for the $\mathrm{M}_{\mathrm{W}}=6.3$ Weber earthquake of 19 February 1990, together with the mean regression curve $(\sigma=0.21)$ obtained using the depth $\mathrm{h}_{\mathrm{e}}=28 \mathrm{~km}$. Horizontal distances were measured in the same way as for the May 1990 event above, and $d=-1$ was again assumed. The regression curve is compared with the model of Joyner and Boore for which the mean and mean $\pm \sigma$ curves are plotted. The depth $\mathrm{h}=28 \mathrm{~km}$ was used instead of the $\mathrm{h}=7.3 \mathrm{~km}$ in equations (6) and (7). It is seen the regression curve lies outside the mean $+\sigma$ line of Joyner and Boore's model out to distances exceeding $80 \mathrm{~km}$ from the source. The PGAs predicted by the model increase notably at near distances (eg: $\times 1.75$ at $20 \mathrm{~km}$ ) when $\mathrm{h}=7.3 \mathrm{~km}$ is used, but still underestimate (eg: $\times 0.72$ at $20 \mathrm{~km}$ ) the regression curve. Although not plotted here the relationships of the other overseas models to the regression curve are similar to those shown for the May 1990 event. Similarly in the figures relating to the other events presented below the visual comparisons are restricted to the Joyner and Boore model.

In Figure 4 are plotted the PGA data for the $\mathrm{M}_{\mathrm{W}}=5.8$ Hawks Crag I earthquake of 28 January 1991, together with the mean regression curve obtained using the depth $h_{e}=10 \mathrm{~km}$. As the aftershocks have not been plotted for the Hawks Crag events, distances from the fault rupture cannot be properly measured so horizontal distances were measured from the epicentre. This implies quite large uncertainties in the distances to the two recordings made nearest to the source. Two regression curves are plotted in Figure 4, one obtained with $d=-1(\sigma=0.24)$ and the other obtained leaving $\mathrm{d}$ free $(\sigma=0.19)$. The great difference in shape of these curves illustrates how the data from a single event needs to be related to an attenuation pattern established from many events. As discussed above there is reason to believe that $d$ should have a value somewhere close to -1 . For this event, without this constraint, the regression analysis is dominated by the record obtained nearest to the source from the rock site at Te Kuha, and the relatively high response at $r_{h} \approx 60 \mathrm{~km}$ recorded at Murchison, with soft deposits over deep alluvium. Similar to the Weber events, Figure 4 shows that the preferred regression curve for the Hawks Crag I event represents substantially larger PGA's than those predicted by Joyner and Boore's model using $h=7.3 \mathrm{~km}$, at all distances. The Hawks Crag II event shows similar (but greater) differences to Joyner and Boore's model (Table 3 ).
In Figure 5 are plotted the PGA data for the $\mathrm{M}_{\mathrm{w}}=6.0$ Lake Tennyson earthquake of 10 February 1990 , together with the mean regression curve $(\sigma=0.24)$ obtained using the depth $\mathrm{h}_{\mathrm{e}}=8 \mathrm{~km}$. Horizontal distances were measured in the same way as for the Weber events above, and $d=-1$ was again assumed. The regression curve is here found to be virtually identical to the Joyner and Boore model, in which their depth term $\mathrm{h}=7.3 \mathrm{~km}$ was used for this shallow event. This very close correspondence of the regression analysis curve with the Joyner and Boore model is the exception amongst the events studied here. The next closest match with Joyner and Boore's model was with the Edgecumbe earthquake regression (Table 3).

An overview of the comparison of the New Zealand data with the foreign models may be obtained by calculating the ratio of the PGA obtained from the regression to that obtained from the model, i.e.

$$
\rho=\frac{P G A(\text { regression, this study) }}{P G A \text { (model, e.g. Joyner and Boore })}
$$

$\rho$ is calculated at a range of distances from the centroid of the rupture surface, $\mathrm{r}=20,50,100 \mathrm{~km}$.

In Table 3 values of $\rho$ are given for our seven shallow events for two models, (1) Joyner and Boore and (2) Fukushima and Tanaka. It is seen that $\rho=0.94-2.68$ for the Joyner and Boore model, with a mean of $\bar{\rho} \approx 1.7$ at both $r=50$ and $100 \mathrm{~km}$ and $\bar{\rho} \approx 1.5$ at $\mathrm{r}=20 \mathrm{~km}$. As can be seen from Figure 2, the ratios $\rho$ for the Campbell model and the European one of Ambraseys and Bommer will be much the same as those found for the Joyner and Boore model. The above findings are supported by a recent study of spectral accelerations $S_{a}$ of New Zealand earthquakes [3], in which the local model for $S_{a}$ at a period of $0.2 \mathrm{~s}$ for earthquakes of $\mathrm{M}=6.5$ was found to be substantially greater than the equivalent model from the western USA.

For the Fukushima and Tanaka model, $\rho$ lies in the range 0.58 1.51 , with a mean $\bar{\rho}=0.97$ at both 50 and $100 \mathrm{~km}$ and $\bar{\rho}=1.04$ at $\mathrm{r}=20 \mathrm{~km}$. Although the number of events being studied is not great, this result is consistent with the choice of the Japanese model of Katayama as the starting point for a New Zealand model for attenuation of spectral accelerations [2]

As has been done elsewhere $[13,20]$, the effect of source mechanism was briefly examined. For the reverse fault events (excluding Te Anau) the PGA are about 10 percent stronger than for the normal and strike-slip events, but the numbers of events in our samples are too small for this result to be statistically robust.

In Figure 6 are plotted the PGA data for the $\mathrm{M}_{\mathrm{w}}=6.7$ Te Anau earthquake of 3 June 1988, together with the mean regression curve $(\sigma=0.22)$ obtained using the depth $\mathrm{h}_{\mathrm{e}}=60 \mathrm{~km}$. In this case horizontal distances were measured from the vertical projection of the centroid of the rupture surface, as the differences between these distances and shortest distances from the rupture were negligible. It was again assumed that $\mathrm{d}=-1$. Joyner and Boore's model using depth $\mathrm{h}=60 \mathrm{~km}$ is plotted on Figure 6 and is seen to greatly underestimate PGA by a factor of 4 for this intermediate depth event. Seismologists point out that such a deep event is unlikely to be modelled well by a model based on shallow events, and this event certainly supports the likely need for attenuation models purpose-made for different depth ranges. 
Table 3: Ratio, $\rho$, of PGA from regression analysis of data from NZ shallow events, against PGAs predicted by US and Japanese attenuation models

\begin{tabular}{||l|c|c|c|c||}
\hline \multirow{2}{*}{$\begin{array}{c}\text { Event Name } \\
\text { (See Table 1) }\end{array}$} & \multirow{2}{*}{ Model } & \multicolumn{3}{|c|}{ Source Distance, r } \\
\cline { 2 - 5 } & & $\mathbf{2 0} \mathbf{~ k m}$ & $\mathbf{5 0} \mathbf{~ k m}$ & $\mathbf{1 0 0} \mathbf{~ k m}$ \\
\hline 1. Edgecumbe & J and B & 1.08 & 1.19 & 1.20 \\
& F and T & 0.73 & 0.60 & 0.62 \\
\hline 3. Doubtful Sound & J and B & NA & 2.02 & 2.68 \\
& F and T & & 1.10 & 1.43 \\
\hline 4. Lake Tennyson & J and B & 0.94 & 0.99 & 1.07 \\
& F and T & 0.64 & 0.58 & 0.64 \\
\hline 5. Weber I & J and B & NA & 2.43 & 1.68 \\
& F and T & & 1.34 & 0.92 \\
\hline 6. Weber II & J and B & 2.25 & 2.03 & 1.72 \\
& F and T & 1.51 & 1.10 & 0.92 \\
\hline 7. Hawks Crag I & J and B & 1.50 & 1.54 & 1.62 \\
& F and T & 1.05 & 0.95 & 1.03 \\
\hline 8. Hawks Crag II & J and B & 1.85 & 1.93 & 2.05 \\
& F and T & 1.27 & 1.13 & 1.22 \\
\hline \hline Mean $\rho$ excluding & J and B & 1.52 & 1.73 & 1.72 \\
Te Anau event & F and T & 1.04 & 0.97 & 0.97 \\
\hline \hline
\end{tabular}

\footnotetext{
Notes: $\quad \mathrm{NA} \quad=$ Not applicable, as least source distance exceeds chosen value

$\mathrm{J}$ and $\mathrm{B}=$ Joyner and Boore - see equation (6)

$\mathrm{F}$ and $\mathrm{T}=$ Fukushima and Tanaka - see equation (9)
}

\section{CONCLUSIONS}

In this study of the peak ground accelerations in eight recent New Zealand earthquakes, attenuation regression analyses were compared with four models from other parts of the world, i.e. two from the western USA, one from Europe and one from Japan. The $1988 \mathrm{Te}$ Anau earthquake of depth $60 \mathrm{~km}$ from the Fiordland region appears to be exceptionally different from all the foreign models, and needs further study. Taking the remaining seven shallow events as a set, they fit the Japanese model [21] well, although some aspects underlying that model are questionable. The models from the western USA $[18,20]$ and Europe [19] substantially underestimate the PGAs at distances of up to $100 \mathrm{~km}$ from the source; the New Zealand PGAs on average are about 1.7 times the predictions of these models at source distances of 50 and $100 \mathrm{~km}$, and 1.5 times at $20 \mathrm{~km}$ distance.

The Te Anau earthquake had $M_{W}=6.7$, while the seven shallow events considered had magnitudes in the range $\mathrm{M}_{\mathrm{W}}=5.8-6.5$. Hence considering the relatively small number of events and the moderate magnitude range, the above results should only be used as an interim guide for the distance and magnitude ranges considered. The authors will be studying the whole New Zealand data set in 1993 in an attempt to produce a reliable local PGA attenuation model.

\section{ACKNOWLEDGEMENTS}

The authors are grateful for data on source parameters provided by our seismologist colleagues $\mathrm{H}$ Anderson, $\mathrm{R}$ Robinson and $\mathrm{T}$ Webb. We also thank $J$ Zhao for his assistance with the regression analysis, $\mathrm{G} \mathrm{H}$ McVerry for a constructive in-house review, and similarly an unknown reviewer.

\section{REFERENCES}

1. T Matuschka (1980) "Assessment of seismic hazard in New Zealand", Report No. 222, Department of Civil Engineering, University of Auckland.

2. T Matuschka, K R Berryman, A J O'Leary, G H McVerry, W M Mulholland and R I Skinner (1985) "New Zealand Seismic Hazard Analysis", Bulln. NZ National Soc. for Earthq. Eng., 18, 313-322.

3. T Matuschka and B K Davis (1991) "Derivation of an attenuation model in terms of spectral accelerations for New Zealand", Proc. Pacific Conference on Earthquake Engineering, Auckland, 2, 123-134.

4. D J Dowrick (1990) "Magnitude reassessment of New Zealand earthquakes", Earthquake Engineering and Structural Dynamics, 20, 577-596. 
5. H Anderson and T Webb (1989) "The rupture process of the 1987 Edgecumbe earthquake, New Zealand", NZ Jnl of Geology and Geophysics, 32, 43-52.

6. Phys. Earth Planetary Interiors, various issues.

7. H Anderson, T Webb and J Jackson, "Focal mechanisms of large earthquakes in the South Island, New Zealand; implications for the accommodation of Pacific-Australia plate motion", submitted to Jnl Geophysical Research, 1992.

8. H Anderson and T Webb, DSIR Geology and Geophysics, Wellington, pers. comm., 1992.

9. Bulln Intl Seism Centre (England) various issues.

10. National Earthquake Information Center, US Geological Survey, "Preliminary Determination of Epicentres", various issues.

11. D J Darby (1989) "Dislocation modelling of the 1987 Edgecumbe earthquake, New Zealand", NZ Jnl of Geology and Geophysics, 32, 115-122.

12. T C Hanks and H Kanamori (1979) "A moment magnitude scale", Jnl Geophysical Research, 84, 2348-2350.

13. D J Dowrick (1992) "Attenuation of Modified Mercalli intensity in New Zealand earthquakes", Earthquake Engineering and Structural Dynamics, 21, 181-196.

14. D J Dowrick (1991) "A revision of attenuation relationships for Modified Mercalli intensity in New Zealand", Bulln. NZ National Soc. for Earthq. Eng., 24, 210-224.

15. DSIR Physics \& Engineering Laboratory (1988) "Computer analyses of New Zealand earthquake accelerograms", Vol 3, Dept of Scientific and Industrial Research, Lower Hutt.

16. DSIR Physical Sciences (1991) "Computer analysis of New Zealand earthquake accelerograms", Vols 5 and 6, Dept of Scientific and Industrial Research, Lower Hutt.
17. DSIR Physical Sciences (1991) "Computer analysis of New Zealand earthquake accelerograms", Vol 7, Dept of Scientific and Industrial Research, Lower Hutt.

18. W B Joyner and D M Boore (1981) "Peak horizontal acceleration and velocity from strong-motion records including records from the 1979 Imperial Valley, California, earthquake", Bulln. Seism. Soc. of America, 71, 2011-2038.

19. N N Ambraseys and J J Bommer (1991) "The attenuation of ground accelerations in Europe", Earthquake Engineering and Structural Dynamics, 20, 1179-1202.

20. K W Campbell (1981) "Near-source attenuation of peak horizontal acceleration", Bulln. Seism. Soc. of America, 71, 2039-2070.

21. Y Fukushima and T Tanaka (1990) "A new attenuation relation for peak horizontal acceleration of strong earthquake ground motion in Japan", Bulln. Seism. Soc. of America, 80, 757-783.

22. W B Joyner and D M Boore (1988) "Measurement, characterization, and prediction of strong ground motion", in "Earthquake engineering and soil dynamics II - Recent advances in ground motion evaluation", Edited by $\mathrm{J} L \mathrm{~L}$ Von Thun, ASCE, Geotechnical Special Publication No. 20, 43-102.

23. B A Bolt and N A Abrahamson (1982) "New attenuation relations for peak and expected accelerations of strong ground motion", Bulln. Seism. Soc. of America, 72, 2307 2321.

24. R Robinson, DSIR Geology and Geophysics, Wellington, pers. comm., 1992.

25. W D Smith (1978) "Spatial distribution of felt intensities for New Zealand earthquakes", $N Z J n l$ of Geology and Geophysics, 21, 293-311. 